\title{
A História dos livros que ajudaram os soldados aliados a vencerem a Segunda Guerra Mundial
}

\author{
Anailza Guimarães Costa
}

Recebido: 01/07/2016

Aprovado: 22/08/2016

A obra Quando os livros foram à Guerra de Molly G. Manning traz uma instigante abordagem sobre como os livros ajudaram os Aliados a vencerem a Segunda Guerra Mundial. A autora mostra que os livros foram peça fundamental na vitória de uma guerra que massacrou milhares de vidas e que além das bombas, projéteis, os livros também foram usados como armas, numa espécie de guerras de ideias.

A obra está dividida em uma introdução, onze capítulos, um epílogo onde a autora fala a respeito do memorial existente na Alemanha lembrando a queima de livros por Hitler em 1933 e dois apêndices, um mostrando uma lista com os nomes dos autores proibidos na Alemanha nazista e outro trazendo uma série de nomes de autores que publicaram na editora americana Armend Services Editions, criada durante a durante a Guerra.

A autora Molly G. Manning têm mestrado em História Americana pela Universidade da Albânia, doutorado em Direito e foi também autora da obra The Myth of Ephraim Tutt. Segundo Manning, ela descobriu os livros da Armed Services Editions enquanto examinava uns arquivos para seu primeiro livro e ali ela encontrou inúmeras cartas de membros das Forças Armadas que continham seus sinceros agradecimentos à editora pelo fornecimento de livros gratuitos para iluminar os dias pesados daqueles combatentes. Molly Manning diz que imediatamente ficou intrigada, fascinada e a partir daí começou a querer saber mais sobre esses tais livros que tinham ajudado tanto aqueles soldados e os resultados dessas pesquisas encontram-se nessa obra publicada em 2015.

Molly Manning retrata em Quando os livros foram à Guerra a História do cotidiano dos soldados, as dificuldades enfrentadas no dia a dia de um combatente que lidava com a morte o tempo todo. Quando falamos no estudo da Segunda Guerra Mundial encontramos diversas produções, afinal é um dos assuntos mais publicados. Porém, vemos mais relatos sobre as estratégias militares, holocausto, judeus, nazismo.

Quando nos deparamos com informações sobre o dia-a-dia destes soldados, ficamos intrigados ao ver a extensão da dor de uma guerra. Vemos que ela ia além das bombas e dos tiros. Os soldados enfrentavam uma combinação de adversidade, exaustão, tédio e medo. O cotidiano de um soldado consistia muito mais em espera do que em luta. Essas informações e relatos de soldados é o que mais temos de precioso no livro de Manning. A autora inova ao usar as cartas que os soldados americanos enviaram agradecendo as editoras como fontes. Através dessas, Manning construiu esse dia-a-dia penoso do combatente e mostrou como os livros ajudavam nesse sentido.

Além de relatar todo esse cotidiano, Manning mostra que os norte-americanos reconheceram que era também uma guerra de ideias e que os Estados Unidos criaram todo um aparato para suprir de livros os soldados. Logo no capítulo 1 "Uma fênix vai renascer", Manning fala sobre a queima de livros a mando de Hitler na Alemanha em 1933. Neste capítulo a autora discorre sobre o aparato criado por Hitler para proibir 


\section{A HISTÓRIA DOS LIVROS QUE AJUDARAM OS SOLDADOS ALIADOS A VENCEREM A SEGUNDA GUERRA MUNDIAL}

\section{ANAILZA GUIMARÃES COSTA}

livros e filmes que não estivessem de acordo com as ideologias nazistas. A autora mostra que os Estados Unidos foram na contramão, pois, enquanto na Alemanha os livros foram proibidos e queimados, os norte-americanos faziam campanhas de incentivo a leitura e doações de livros.

Estas começaram com a Campanha Nacional de Defesa do Livro (NDBC), depois mudada para Victory Book Campaign (VBC) que arrecadou milhares de livros para os soldados, uma espécie de "bibliocausto" ou resposta a queima de livros feita pelos alemães. Além dos incentivos a leitura, existia uma preocupação maior: como esses livros poderiam ser mobilizados para guerra? A autora mostra que houve reuniões, discussões e a partir daí projetos foram colocados em prática. Obras que esclarecessem os motivos pelos quais os Estados Unidos estavam em guerra, os valores que estavam em jogo. Obras de autores eram selecionadas e recebiam etiquetas com a palavra Imperative (Fundamental) e capas adornadas com um grande "I".

Além disso, Manning mostra que existia uma preocupação com os livros que iam além do conteúdo. Uma preocupação com o papel, formato da letra e tamanho. Mesmo na Guerra, onde papel, dinheiro e mantimentos estavam escassos, a produção de livros foi colocada como prioridade para os norte-americanos. Inicialmente as obras eram publicadas em capa dura, num tamanho maior. Mas, por ficar mais viável para os soldados carregarem, a partir daí surgiram os livros de bolsos, com capa mole.

A autora mostra em vários relatos que assim os soldados conseguiam carregar os livros nos bolsos durante as batalhas e ler entre um descanso. Eles faziam questão de escrever cartas agradecendo aos escritores pela preciosa leitura e relatavam como os livros os ajudavam. Em Quando os livros foram à Guerra Manning traz diversas imagens interessantes que mostram os combatentes lendo as obras em situações mais extremas, como deitados em palafitas em acampamentos destruídos ou quando estavam hospitalizados.

O sucesso dos livros da ASE (Armed Services Editions) chegou aos ouvidos de outros soldados como os britânicos, que a partir de 1944 começaram também a produzir obras em miniaturas. Mesmo após o término da Guerra, os livros ainda continuaram sendo publicados a pedido de muitos soldados. Manning nos mostra que também existiu uma preocupação de adaptar o conteúdo das obras a realidade pós-guerra. Só em 1947 o programa de livros da ASE chegou ao fim e mesmo assim ainda o conselho recebeu inúmeras cartas dos soldados que sentiram falta da cota mensal de livros.

Quando os livros foram à Guerra nos mostra vários aspectos do cotidiano dos soldados durante a Segunda Guerra e traz, sobretudo, a importância da leitura para formação do homem. A autora chega a dizer que se não fossem pelas montanhas de livros que foram enviadas aos campos de treinamento e às unidades no exterior durante a Guerra, muitos homens jamais teriam desenvolvido o interesse pela leitura, pelo estudo ou pela retomada de sua formação e que os livros foram um prazer irresistível até mesmo para aqueles que antes da guerra rejeitavam a leitura. Além disso, observamos que os livros foram usados como armas durante a Guerra. Ajudavam não só o soldado a manter o equilíbrio como também incutiam ideologias, incentivavam a lutarem com força por um ideal.

A obra de Molly G. Manning é indicada a todos aqueles amantes da história dos livros e da Segunda Guerra. Um livro instigante, bem dividido entre os capítulos e de 


\section{A HISTÓRIA DOS LIVROS QUE AJUDARAM OS SOLDADOS ALIADOS A VENCEREM A SEGUNDA GUERRA MUNDIAL}

\section{ANAILZA GUIMARÃES COSTA}

uma leitura quase literária. Traz um diálogo forte com as fontes, através de imagens e descrições das cartas que os soldados enviavam as editoras.

\section{Nota}

\footnotetext{
' Graduada em História (UFS), mestranda do Programa de Pós-Graduação em Educação (PPGED/UFS), Bolsista CAPES. Integrante do Grupo de Estudos do Tempo Presente (GET/UFS/CNPq), e-mail: anailza@getempo.org. Orientador: Prof. Dr. Dilton Cândido Santos Maynard (DHI/UFS).
}

\section{Referência Bibliográfica}

MANNING G. Molly, Quando os livros foram à Guerra: as Histórias que ajudaram os Aliados a vencer a Segunda Guerra Mundial. Tradução: Carlos Szlak, Rio de Janeiro: Casa da Palavra, 2015. 